\title{
RURAL EDUCATION AND ECONOMIC DEVELOPMENT
}

\author{
Anis Mahomed Karodia \\ Tajna Maharaj \\ Nolwazi Dlamini \\ Tarisma Maharaj \\ Professor and Senior Faculty Member and Researcher at the Regent Business School, Durban, South Africa \\ Lecturer at the Regent Business School, Durban, South Africa \\ Administrator at the Regent Business School, Durban, South Africa
}

\begin{abstract}
:
This paper looks at rural education and its relationship and importance to economic development in the context of South Africa. It is important to political and social discourse given rampant unemployment in South Africa and the stimulation of the South African Economy. That many of South Africa's provinces are largely rural provinces and therefore agricultural development must be a key focus area. The manner in which we teach, model and orientate the teaching of agricultural subjects at school level, therefore assumes great significance from a practical perspective. That many of the provinces are situated within the maize quadrangle, and other rich agricultural landscapes, rich in cattle and wild life and general agricultural activity and therefore, their role is most significant to agricultural development and allied primary and secondary agricultural activity. That fundamental issue within agriculture is a question of access to land and indeed, opportunity for all. That almost all economies are largely rooted in agriculture and so are Adult Basic Education and Training programmes. It is against this background that the paper will project upon and discuss rural education in the context of economic development.
\end{abstract}

\section{INTRODUCTION}

Universal education is a prominent objective in government policy and is therefore, a relatively new idea in South Africa. Until 1994, the education system was geared to the social and economic elite of the country and barely touched the masses. Literacy and the enrolment rates remain low within the open-door-policy, in a democratic South Africa, the need for more vigorous efforts in the fields of education and manpower planning has become even more acute. Policy in the past had been pre-occupied with education as an investment in human capital that affected the supply of labour. But the government of today also recognizes that, education is desirable for its own sake as a final consumption good that, establishes a level of literacy and early drop-out rates from the education system, offer a continuing challenge to the government in its desire to attain this objective.

\section{DISCUSSION}

The governments' education policy, is to equalize economic and social opportunity- and in time, income -by extending education to as wide a base of society as possible. It also aims at meeting man power requirements of the economy, especially the agricultural and industrial sectors. 
Having in some way set the pace and theme of my topic for this opening lecture, I request your patience, attention and understanding as , I sojourn or journey through my topic "Rural Education and Economic Development.

Norman W. Manley, Prime Minister of Jamaica, said: 'Freedom is expression of the creative in life. It is neither an inherit right nor a hard won value. It is a law of being; lacking which there would be no evolution, no progress no civilization, only primal chaos set in permanance'.

We have to as South Africans, seven years down our democracy, having ushered in freedom, ushered in a new century and having the experience of having lived in two centuries- under oppression and within democracy, charter a new course to development and particularly rural and agricultural development and indeed agricultural education.

It is an old and widely held belief that, education can contribute to economic development, but neither educators, nor economists, have recognized theory of how it happens. Educators expertise in curriculum development does not prepare them to identify types of education that will promote economic development, while economists expertise in price theory, has been less useful than many expected. Despite considerable refinement of their measures, the economic value of educational resources, economists are unable to advise educational policy-makers reliably on how to change low-productivity communities into high-productive ones.

My topic suggests that another kind of economic expertise-theory of effects of technology on institutions-can show educational policy makers, reliably on how to contribute to economic development. It presents the economic function of education to be the transmission of technologically relevant skills. Absence of discussion, colleagues, ladies and gentlemen, of existing conditions and obstacles to development reflects this intent and, is not evidence of my ignorance of them.

Technology is total stock of human know-how that is applicable to physical phenomena. It is operational scientific knowledge, the body of techniques and tools capable of producing real income. It has grown cumulatively throughout human history and, is clearly continuing factor in human experience. Every community, every institution, every agricultural educator, must apply some fraction of this stock to survive, while it and they must borrow or improve such know-how in order to develop.

One universal function of education has been to prepare youth to apply the prevailing technology in existing occupations. Such education is traditionally called vocational, meaning, the transmission of manual skills. But the spread of industrial revolution during the nineteenth century, made technology increasingly dependent on mental skills of scientific inquiry and revealed the possibility of purposely borrowing and improving technology, activities which may be called technological inquiry. It is instructive to examine when, where, and how the educational policy-makers added new curricula appropriate to scientific and technological inquiry to vocational curricula traditionally provided for rural youths.

The common technology practiced in 1880 has often been identified as the handicraft level since individual control of tools was its dominant characteristic. Farmers, who constituted most of the population, used very similar tools and learned skills and rules of the thumb.

In preparing ground for the principal crops- rice, wheat, maize-the common tool was plough pulled by and ox or horse, although hoes were also used. The ploughs were made of wood, but frequently had a bit of cast iron attached to the point. While maize was harvested without tools, ripe rice and wheat were cut with sickles, although in the United States the scythe with cradle was becoming more popular. These common tools required common skills in their design, production, operation and maintenance, but differences in operating techniques and competence 
sometimes made great differences in output. Chinese and Japanese peasants applies the most advanced technology then known, getting high yields by labour-intensive techniques such as irrigating, fertilization and double cropping. Mexican and American farmers generally did not apply such state-of-the art techniques. Although Europeans were beginning to make rapid advances by applying science to agriculture, few in the Americas and Africa, practiced such farming.

Essentially all of the rural population learned to apply these traditional tools and techniques through non-formal 'on-the job' training. Children of farmers learned to design, produce, operate, and repair agricultural tools by participating in simple productive activities and, by observing adults engaged in all stages of the production process. Such education was adequate to transmit the manual skills in materials manipulation needed to apply the prevailing technology, but it was not adequate to transmit mental skills in symbol manipulation needed to borrow or improve the level of technology.

In addition to 'on-the-job' training, however, governments had explicit policies for transmitting information to rural masses, some of which might have concerned technological borrowing. From the beginning of the conquest of the Americas, the Catholic Church provided educational support for the Spanish Crown and sought to transmit to the Indians the European level handicraft technology as well as the Christian faith. And after the Manchu's established their control of China, they enforced the traditional Confucian responsibility of scholar-officials to tell the masses how to behave. They continued the institution of bimonthly lectures in every hamlet, in which the educated elite did not only harangue peasants on proper conduct, but also passed on any technological information they learned. This is your responsibility.

A paradigm shift is required. Commemoration and transfer of technology is the nib of the issue. Unfortunately, by 1880 both of these institutions had decayed and were ineffectual for agricultural education. Not only were scholar-officials corrupt and self serving, but also these traditional educated elites were not in touch with the scientific knowledge that was to become the basis of modern agriculture. Consequently, peasants who were taught no symbol-manipulation skills were without access to higher levels of technology and contribute to farm traditional ways. In contrast, many Japanese peasants and American farmers (excluding enslaved blacks) had some access to higher levels of technology, despite the absence of central government efforts to communicate agricultural technology. Japanese Samurai had not borrowed the lecture system from China, but they had accepted the Confucian responsibility for passing relevant knowledge on the masses. Proof again of your role in agricultural schools, as situated in rural areas. This must be intensified. In short, in 1800 non-formal training within the family was the common policy in each country for transmitting to the farming masses the prevailing handicraft technology. In China and Mexico governmental institutions potential able to encourage borrowing of higher levels of technology existed, but were ineffectual; they were absent in Japan and the masters, but privately sponsored literacy and publications raise and the possibility of technological borrowing and improvement.

At mid -century, farmers in China and Mexico continued to use traditional tools and techniques to produce and often-inadequate income. In Japan, as well there was little change in agricultural practice, although technological development in metallurgy was borrowing and improvement were becoming noble, whilst in many other parts of the world ,including Africa, indigenous technology and achievement was suppressed by politics and colonialism. The history of the contribution by African populations in Egypt, Sudan, Ethiopia and many other African countries, including Asia and the Arab world, is well down intact in respect of the Arts, Sciences 
Architecture, Medicine, Mathematics and Agriculture. Thus there needs to be a revival once again.

Iron ploughs had largely displaced wooden ploughs, and experiments with steel mould boards were showing their superior scouring characteristics on western prairies. These ploughs were designed to plough markers who were becoming increasingly specializes abs skilled at using mathematical techniques to design the best shape for each plough function. Harvesting tools, too were being devised to mechanize that operation, although they had not yet come into common use as had improved ploughs. For example, Cyrus McCormick's hand -rake reaper (patented in 1847) was a horse drawn machine that cut grain effectively but had not yet integrated the ranking and binding operations. It was still constructed mostly of wood, but had metal gears and cutting teeth.

In brief farm youths learned to apply the prevailing technology informally from their parents, but American farmers were shifting from traditional to modern farming. The skills of designing and producing tools were becoming the possession of non-farming specialists, while farmers themselves concentrated on applying new tools and techniques to arise output.

Both farmers and toolmakers came to practice technological inquiry with no help from, curricula in formal education except for broader literacy that made tools and techniques from around the world. The expertise of white know-how, experience and efforts must be intensified

In China and Mexico, and other parts of the world, including Africa, scattered applications of modern farming had not touched the masses, who continue to apply their centuries-old handicraft technology. But in the United States and Japan, science-based technology was becoming common. The new tools and techniques permitted greater output and promoted new educational policies. It is your role and effort that must influence policy in South African Education.

American agriculture had become highly mechanized. The steel plough had been perfected, but was increasingly replaced by more efficient wheeled cultivators and harrows. Harvesting machinery had successfully integrated the operations of mowing, ranking, threshing, cleaning, and bagging grain and in California and the Great Plans; mammoth combines were pulled by teams of 20 or more mules and horses.

Technological inquiry was turning to replacing animal power by motor power and steam tractors were becoming less rare. A large industry designed and produced these tools developing new machines by the use of scientific and engineering principles rather than by trial and error. In addition the farmers who operated and repaired these machines had likewise given up their handicraft skills and applied their latest in respect of advancing scientific knowledge to all sectors of our population, particularly the historically disadvantaged.

Japanese farmers still used small hand tools but tools, but this was not evidence that they practiced traditional agriculture. Wooden plough design and production had moves to the factory, and metal tools with traditional designs were produces in modern ironworks. But while Japanese tools had changed little, their techniques of farming had changed enormously.

The dawn of the new century found no change in educational patterns transmitting agricultural skills, but those patterns were greatly transformed in the United States and Japan.

The national government in the United States became actively involved in agricultural education only after 1862, in which year Congress created the Department of Agriculture and passed the Morrill Act providing land grants to finance colleges in every state. These new institutions were intended to benefit agriculture and the "mechanic arts", but not by imitating literacy colleges or by transmitting manual skills. They were to respond to the newly recognized needs of the 
industrial class for scientific understanding and to provide scientific insight into industrial activities. Their curriculum explicitly promoted technological inquiry and gave new meaning to the often-ignored interdependence of theory and practice.

The early years of land -grant colleges were not promising. On one side were farmers who disdained "book-marking" and thought the only way to learn agricultural techniques was on the job. On the other side were academic professors and presidents, whose abstract knowledge was rarely applicable. The latter had to prove their worth to the former and did so.

A start was made by college personnel collecting information on diverse farming conditions and problems in each state. But even when professors became acquainted with local conditions and how to apply scientific principles to them, agricultural classes attracted a few students. So professors went to the farmers. They organized farm instituted, gave public lectures and attended farm meetings. By the 1880s, these extension efforts were succeeding in showing farmers how science might be useful to them. Gradually, the land-grant institutions developed groups of trained scientists, capable of engaging with both applied and basic research and a constituency of literate farmers, anxious to acquire better technology.

The next step was to expand the knowledge by research activities in experiment stations. After several colleges started the movement, the federal government gave support with the Hatch Act 1887. By 1900 there were 56 experiment stations employing 697 skilled technicians. From those stations came a steady flow of new knowledge that was made available to farmers in classrooms through extension agents and through publications

By contrast, the education of the large body of ex-slaves was largely neglected. Most blacks did not have primary education that would qualify them to enter agricultural colleges, even after these were made available by a second Morrill Act for blacks in 1890. The two famous black institutes -Hampton and Tuskegee-did provide extension courses that took improved tools, seeds, livestock, and fertilizers to rural blacks, but they served more as normal schools than as agricultural schools. They aimed to instill the Puritan work ethic and proper work attitudes into former slaves more than to transmit the skills necessary for scientific and technological inquiry. In Japan, the Meiji government used education as a tool of national development. A department of education was created in 1871, consisting of three bureaus: special (higher) education, common education and technical education, one branch of which dealt with agricultural education. Agricultural colleges were opened, staffed at first by British and Americans. But by 1881, it was recognized that Anglo-American practices had little local relevance; the British instructors were replaced by a German agricultural chemist and soil scientist, whose knowledge would be applied to the small-scale methods indigenous to Japan. In that same year, the government began organizing an itinerant instructor system that sent both college graduates and veteran farmer into almost every hamlet. This institution successfully combined the latest theoretical knowledge with practical local experience, making improved techniques both accessible and acceptable to skeptical peasants. In 1893, a national agricultural. In 1982, a national agricultural experiment station opened and started field experiments comparing seed varieties and cultivation techniques bringing even more rural farmers into contact with scientific and technological inquiry. In 1899, the government began subsidizing prefectural agricultural experiment stations and required every village to establish an agricultural association to inform peasants of new techniques and to enforce their use. At the beginning of the twentieth century, there were 33 experiment stations in the country.

Accompanying these efforts to make higher technology universally available was the government's effort to spread literacy throughout the country. It was realized that scientific 
agriculture could be transmitted efficiently only to people who were able to read and calculate. By 1900, 4 years of schooling were obligatory for all children, and practice was approaching what the law required.

In summary, the beginning of the twentieth century, Chinese and Mexican youths had formal elementary education and learned scientific farming practices from men while acquainted with theoretical knowledge and the local farming conditions in each region. Educational institutions had been created that both raised the level of agricultural technology and transmitted it widely throughout the farming population.

Rural education in China and Mexico had made no contribution to technological development in Japan and United States:

1. It had enabled a significant pool of farmers to practice scientific farming by transmitting the skills necessary to borrow and invest higher levels of technology.

2. It had permitted invention and wide transmission of practical knowledge that enormously increased the productivity of the average farmer and, correspondingly, reduced the number of farmers needed.

3. It had provided comprehensive skills in solving problems through scientific and technological inquiry that permitted youths moving off the farm to productive in myriad non-agricultural occupations

This historical survey provides some evidence for the following hypothesis:

1. In contrast to lower levels of technology, which rarely require mastery of more than manual skills, modern technology depends on mastery of scientific principles and, consequently, on mental skills and manipulating verbal and numerical symbols.

2. The traditional symbol-laden curricula of formal schooling, although designed for purely non-technological ends, do develop skills that are relevant to modern technology.

3. A curricula explicitly designed to promote scientific inquiry (discovering general principles from special-case observation)\} and technological inquiry( discovering special-case applications of scientific principles) will reduce the gap between theory and practice, integrating mastery of numerical symbol-skills with their application, so that the bulk of each nation's population will develop competencies necessary for substance economic development.

Should these hypotheses prove well grounded, they could provide the core of a theory of educational policy for economic developme0nt. The theory would recognize that educational institutions can be adjusted to potentialities inherit in technology. It would reveal that educational resources can be allocate to economic development on the basis of their contribution to a community's skill at borrowing and improving technology rather than on the basis of contribution to incomes and in existing occupations.

Some might argue that this proposed 'theory' is an obscure way to state what most people already know: the rural education would transmit technologically relevant skills. But a brief look at the failures of educational policies in China and Mexico since 1950 suggest otherwise. If the theory suggest why those failures occurred its usefulness will be supported.

Since mid-century the communist parties in China and the Partido de la Revolution institutional in Mexico have made great efforts to achieve technological development in agriculture. Although they have provided many modern inputs and raised the output of many crops, the rural education has failed to achieve technological development. The bulk of the farmers continue to employ traditional, rather than modern, technology because policy- makers have incorrectly understood the economic function of education. 
Education policy in China from the establishment of the People's Republic in1949to the death of Mao Tse-tung in 1976, reflected that educational theory developed by Mao during his decades of revolutionary struggle in rural China. It was based on the belief that learning by doing is the main path to practical knowledge. Because that theory ignored the difference between sciencebased knowledge and traditional common sense, it doubted the practicality of knowledge acquired from books by urban elites and equated formal learning with the ceremonial accomplishments of the traditional Chinese scholar. Accepting the innate wisdom of the masses of the innate virtue of their back-braking labor it helped the theory and practice could only be integrated when the 'educated' theoretician learned from the practitioner.

This educational theory underlay early efforts to achieve to transformation': the socialist transformation and the technical transformation that would raise agricultural output by intensifying and upgrading traditional practices. It underlay the great leap forward in 1958, which sought to integrate theory and practice by having farms operating schools and schools operate farms, so that everyone would become 'red and expert'. It was central to the cultural revolution, started in 1966, in which peasants were to carry out research, and scientist were sent down to the villages to learn from the peasants.

Because Moa tried to substitute the authority of rural commonsense for the authority of scientific and technological inquiry. His policies wasted many resources. Despite expanding literacy- a necessity for technological development - they replace inquiry with political enthusiasm, punishing intellectuals who were competent in inquiry and discouraging peasants who needed to become competent. Those policies and it impossible to transmit scientific agriculture from those who understand it to those who did not, and thus delayed the transmission of Chinese farming from traditional to modern technology.

Recent Educational policies in Mexico reflect meritocratic ideals directly contrary to those of Moa. It is based on the belief that they can be mastered only by technical elite. Because it ignores the difference between refined experiment by experts and technological inquiry by practitioners, it doubts the practicality of transmitting to the general public any meaningful understanding of higher-level knowledge. Accepting the superior wisdom of the expert view, it holds that theory and practice can be integrated only when the 'ignorant' practioner submissively accepts the authority of theoretician.

By focusing on investment on a few high-quality education and economical resources, Mexican agricultural output increased dramatically from the 1940s to the 1960s but has since failed to be self sustaining. The greatest growth has been on modern farms - islands of commercial agriculture in a sea of subsistence farmers- that benefited from large government investments in irrigation, roads, and higher education. Research institutes and colleges turn out skilled technicians and researchers, whose knowledge helps the modern, educated farmer. But such technological development has not been effectively transmitted to the masses: the ignorant peasant is rightly skeptical of the visiting expert who lacks knowledge of local conditions, and who, despite whose low pay, considers himself superior to those he is trying o assist.

Because Mexican Education has sought to impose the authority of the expert without achieving understanding by the masses, the community has not achieved technological development. Despite great expansion of scientific knowledge - identified as the Green Revolution- little benefit has reached the Mexican peasant because rural education has not provided the foundation necessary to join theory with practice. When the practitioner is scornful of the theoretician, or when the theoretician is patronizing to the practitioner, scientific and technological inquiry is thwarted. 
This study does not suggest that any country should imitate the rural education practiced in Japan or in the United States. But it does not argue that success in those countries shows how educational curricula can adjust to the continuously evolving requirements of technological mastery. Its suggests that a nation-wide elementary curriculum that teaches reading and technological problem solving in rural life is a necessary first step for the Chinese and Mexican communities that seek to master modern technology. And it brings into view the logic of adjusting all institutions- not just educational ones- so that the human well-being made possible by rising levels of technology will be realized, translating the potential of technological progress into actual economic development.

My paper was perhaps boring and lengthy but in underscores that we require innovative curriculum change, we require new methodologies, we require more practical training and outreach programmes, we require innovation and innovative teaching methods and above all, to define how students, agricultural educators and agricultural schools can play a role to enhance their efforts within communities.

Having crystallized some aspects of rural economic development, it is important to reflect on governments' most recent rural development programmes announced by the President in his speech at the opening of parliament the other day, as exemplified by the Deputy President in terms of a plan of action. Such a plan will be financed by all three spheres of government.

In a document titled the "Integrated Sustainable Rural Development Strategy", municipalities will have to come up with plans before making a bid for funds in the budgets of national and provincial departments. The document alludes to the shortage of skills in rural areas and therefore, the future of agriculture and agricultural education and training is secure. The document further indicates that over and above primary indicators of input and out that South Africa's rural development strategy over the short, medium and long term will rest heavily on students being trained in all facets of agriculture and this will be dependent upon the quality of agricultural education at both school and tertiary level.

Ii further ads crucially an important complementary measure to the rural development programme would be land reform that, could lead to the burgeoning of small-scale farmers, who must be equipped via adequate and quality agricultural education via our agricultural schools.

Ladies and Gentlemen, your input and your role are therefore crucial and vital to the success of this renewal programme to rural economic development. If land reform dragged on the agricultural sector and therefore the entire rural sector is at risk.

On the other hand land reform will result in rural areas receiving liquidity boost and so will agricultural education. The government will therefore be obliged to also help kick-start community-based income generating projects such as irrigation schemes and small dams for livestock according to the document.

Key services in rural towns would increase the multiply of incremental incomes and therefore agricultural education is key to rural economic development.

\section{CONCLUSION}

Finally, one needs to reflect on:

1. How to engineer the Outcomes Based Education OBE agricultural syllabus;

2. To invoke constant review

3. To establish norms in testing, but testing the agricultural student on what he knows, not what he does not know;

4. To allow for more practical training; 
5. Not to load the question paper with mathematics;

6. Proper counseling of students in respect of subject selection;

7. Constant interaction with agricultural schools;

8. The role of subject advisers must be defined;

9. Interaction with colleges and universities to be intensified;

10. Training for the market. Training not for government jobs but for private enterprise and commercial agriculture;

11. Training for Research, to work with communities/ outreach programmes; and

12. A host of other issues

\section{BIBLIOGRAPHY}

This paper is extracted from a speech given by Professor Karodia at the Agricultural Schools of the North West Province of South Africa in 2006, at Wagpos Agricultural School in the North West. In addition a number of sources were used to construct the thrust of the paper and primarily observations gleaned whilst the principal author was the Director General of Education in the North West Province of South Africa.

\section{Acknowledgements:}

The principal author wishes to thank the co - authors for their insights, reading the manuscript and positively contributing to the structure of the paper. 